\title{
The Effects of Trained Peer Feedback for High School Students
}

\author{
Vu Phi Ho Pham ${ }^{1}$, Truong Chinh $\mathrm{Le}^{2}$, The Hung Phan ${ }^{1} \&$ Ngoc Hoang Vy Nguyen ${ }^{3}$ \\ ${ }^{1}$ Faculty of Foreign Languages, Van Lang University, Ho Chi Minh City, Vietnam \\ ${ }^{2}$ Hoa Minh High School, Tra Vinh Province, Vietnam \\ ${ }^{3}$ Institute of Linguistics, Van Lang University, Ho Chi Minh City, Vietnam \\ Correspondence: Vu Phi Ho Pham, Faculty of Foreign Languages, Van Lang University, Ho Chi Minh City, Vietnam.
}

Received: June 25, 2021

doi:10.5430/wjel.v12n1p27
Accepted: October 11, $2021 \quad$ Online Published: October 26, 2021

URL: https://doi.org/10.5430/wjel.v12n1p27

\begin{abstract}
Peer feedback is proved to be effective in helping enhance students' writing quality, but few studies were employed to train high school students to be better peer reviewers. The current study involved 64 grade-11 students in a province in Vietnam to see whether trained peer feedback could be effective for high school students. The experimental group was trained to conduct peer feedback, while the control group did it naturally. The semester lasted for 16 weeks. Data collection was from the pre-test, post-tests, and semi-structured interviews. The results revealed that the most common errors that the students committed were grammar (verbs, articles, repositions), followed by vocabulary (word order, word choice, word form), and mechanics (capitalization, spelling, punctuation). In addition, the students in the experimental group who received peer feedback training could significantly reduce the written errors in the post-test. The students obtained positive attitudes towards peer feedback activities in the writing classroom.
\end{abstract}

Keywords: peer feedback, writing errors, writing mistakes, error reduction, students' attitudes

\section{Introduction}

Writing is a complex and deliberate action that includes a variety of internal processes and an external environment. Additionally, writing is frequently self-directed, self-initiated, and self-sustaining (Zimmerman \& Risemberg, 1997). As a result, it is asserted that the growth of students' writing abilities is contingent upon their level of self-regulation (Graham \& Harris, 2000). One of the most significant problems EFL instructors confront in the classroom is with writing. In the Vietnamese context, students must be able to comprehend the gist of paragraph writing. They are expected to write simple paragraphs relating to familiar or personal topics of interest and describe experiences. However, writing skills are always problematic for Vietnamese students (Pham \& Bui, 2021).

Many researchers worldwide have employed peer feedback activities in their writing classrooms (Pham \& Nguyen, 2020). Peer feedback on students' writing is critical, and its usefulness has been extensively established in ESL writing studies (Jacobs, 1987; Mangelsdorf \& Schlumberger, 1992; Tsui \& Ng, 2000). Keh (1990) and Pham (2021) claimed that writing is the process through which many forms of peer criticism may be carried out, including written comments, discussion of the paper, and checklist use. According to Shrum and Glisan (2000), reacting to writing simply means that the instructor corrected students' grammar, vocabulary, and other common problems. According to Jacobs (1987), peer feedback is frequently acknowledged as a way for students to read and constructively evaluate one another's writing. Especially in large classes, one of the critical factors to consider when providing feedback is the components of writing that should be emphasized, as well as specific components of writing, such as content, organization, and language use (i.e., grammar, vocabulary, and mechanics) (Pham \& Nguyen, 2014), or on a specific component of writing, such as grammatical errors, diction, or content (Weigle, 2002). In other words, providing feedback is a process of giving and receiving from peers, emphasizing form and content.

There have been numerous advantages to incorporating peer feedback into writing classrooms (Pham \& Nguyen, 2020). Tsui and $\mathrm{Ng}$ (2000) have shown that peer comments help students develop an authentic feeling of audience, a sense of ownership over the piece, and a knowledge of their own writing's flaws. Most importantly, participating in peer comment sessions enables students to learn from their peers' errors and well-written pieces of writing, allowing them to grow as writers. As a result, feedback is viewed as an educational tool for enhancing students' writing abilities. Students do not work alone or keep their thoughts to themselves while they are engaged in writing. Instead, Published by Sciedu Press 
they are involved in the reaction, assessment, evaluation, and modification processes. The students' peer feedback and evaluation activities have a significant influence on their writing development. In practice, peer feedback also aids students in developing their writing abilities by promoting their critical thinking. Another advantage is that it improves students cognitively by encouraging them to think instead of receiving criticism from the teacher and has certain social benefits (Damon \& Phelps, 1989). In addition, providing peer feedback to students enables them to express their thoughts and obtain constructive criticism from their peers to improve their writing on each draft. As a result, students can modify their drafts.

Additionally, students have the opportunity to identify barriers in their writing. According to Lundstrom and Baker's (2009) study, feedback providers made more substantial advances in their writing than feedback recipients, while feedback providers with lower language competence made more significant gains than feedback recipients with better language proficiency. Additionally, their research found that feedback providers improved global (organization, development, and coherence) rather than local (vocabulary, grammar, and mechanics) elements of second language writing.

\section{Literature Review}

Numerous scholars throughout Asia recognized that identifying the students' written errors would aid them in adjusting their teaching activities. As they found the students' comment written mistakes, they knew what to focus on in their lesson. According to Khansir and Pakdel (2020), issues involving error analysis approaches in English language acquisition have been frequently studied for more than sixty years. Today, the error analysis approach is still widely and effectively used in English language learning. Ho (2014) also noted that students frequently struggled with concept organization, grammatical usage, transitional wordings, and word usage in writing classes.

Many researchers investigated the students' written errors and claimed similar findings. Bahrpeyma and Ostad (2018), Chan (2010), Darus and Ching (2009), Pham and Pham (2015), Pham and Do (2019), and Salehil and Bahrami (2018) found that when the students composed their writing, they regularly committed to some common errors, such as tenses, collocations, spelling, word uses, and verb forms. These studies' four most common errors were mechanics, tenses, prepositions, and subject-verb agreement.

Rahimi and Tafazoli (2014) analyzed the written mistakes made by undergraduate EFL students at Islamic Azad University in Iran. According to their findings, Iranian EFL students made mistakes in using articles, verb groups, prepositions, and incorrect negative constructions. They stated that the most frequent errors in this endeavor were in the papers. Yousefi, Soori, and Janfaza (2014) studied the prepositional mistakes produced by Iranian EFL learners in the English language and discovered that prepositional errors were the most often made.

In other words, writing in English is difficult for most Asians who have studied English as a foreign language. Writing is sometimes touted as the most challenging talent to master compared to the other three: listening, speaking, and reading. Due to its intricacy, feedback is viewed as a critical component of the writing process since it can improve students' writing skills. It has been agreed that instructor feedback is impractical in a class with a large number of students; consequently, peer feedback in the writing classroom faces significant obstacles (Kusumaningrum, Cahyono, \& Prayogo, 2019).

Gielen et al. (2010) conducted comparative research of peer and teacher feedback in a secondary school writing curriculum and other kinds of peer feedback. The study discovered no significant difference between students who received substituted peer input on writing projects and those who received instructor feedback in the control group. This study suggested that peer input can be an effective substitute for instructor feedback. Additionally, the peer feedback approach improved students' critical thinking, confidence, originality, drive, and writing ability. Farid and Samad (2012) identified the most prevalent types of feedback, which fall into two broad categories: content feedback and form feedback. Additionally, research indicates that direct feedback is more beneficial than indirect input.

Cahyono and Rosyida (2016) performed a research study on Indonesian EFL students' peer feedback, self-correction, and writing competency to determine the efficiency of peer feedback and self-correction based on guideline sheets. Seventy-one sophomore students who attended an essay writing course participated in this study. Students in all three classes utilized identical writing materials that were based on a textbook. This study concluded that peer criticism and self-correction based on guideline sheets benefit the writing process. The students enhanced their writing abilities via the use of peer criticism based on established guidelines. As a consequence, peer input was helpful in assisting students in improving the quality of their writing.

Altstaedter (2018) studied the effect of peer feedback on students' written comment kinds and writing quality. Students in quasi-experimental groups were given a set of rules to follow while offering comments on their partners' 
writing. The study's findings indicated a statistically significant difference in the number of comments students supplied following the training vs. the number of comments made before the training. This demonstrated that peer criticism has a variety of effects on students' writing abilities.

Similarly, Park (2018) investigated whether teacher and peer feedback can be effectively applied in a university-level EFL writing classroom. The study examined instructor and peer feedback features and students' actual use of feedback, and their opinions of its usefulness. The study included twenty students majoring in the English language. The findings indicated that instructor feedback was more balanced than peer feedback, indicating that both types have their merits. However, they favored an integrated instructor complements. As a result, peer criticism enhanced the writing ability of EFL students, particularly in terms of paragraph organization, grammar, and vocabulary.

Kusumaningrum et al. (2019) examined the influence of two different forms of peer feedback on students' writing performance. The researcher divided the students into two different groups. The first was peer feedback in class, in which any student may offer comments to another student who presented writing in class. While the other was a small group activity with peer input, in which students may offer comments to one another in a small group setting. Prior to students providing input, they were instructed on how to provide feedback to their peers in an in-class or small group setting. The findings of this study indicated that students improved their writing skills after being exposed to either in-class peer feedback or small group peer feedback.

Pham, Huyen, and Nguyen (2020) performed research to examine the impacts of peer feedback in writing classes since this type of feedback may be quite beneficial when teaching L2 writing. There were 92 pupils in all, 45 from Writing- 1 and the remainder from Writing-3. A trainer supported the researcher in working with both groups, and a coder-rater assisted the researcher in coding and evaluating participants' drafts. The purpose of this study is to determine the quality of trained written peer criticism and its influence on students' modifications. The findings indicate that the majority of peer comments were revision-oriented and that the number of accurate comments was significantly more than the number of miscorrections.

Regarding students' opinions of peer feedback activities, Farrah (2012) asserted that students saw peer feedback as a beneficial experience since it allowed for social contact while improving students' writing abilities. Yastbaş (2015) discovered that students had a favorable attitude toward peer feedback and felt that it might help them overcome their writing fear and increase their confidence in writing classes.

In summary, prior research has revealed that most Asian students routinely commit basic errors in grammar, articles, prepositions, and word use. Writing teachers should be aware of these difficulties to assist students in developing their writing abilities. Additionally, peer feedback was a beneficial practice in writing classes to assist students in correcting such types of mistakes. However, in the research setting, high school instructors frequently overlooked this issue. They seldom used this type of activity in writing courses, assuming that high school pupils had a limited degree of English competence. They just could not afford it. Thus, the purpose of this study was to examine the effects of peer feedback on high school students' paragraph writing performance, as well as to define how students improve their writing after receiving peer feedback, as well as students' attitudes toward receiving and providing feedback on their peers' writing.

\section{Research Questions}

In order to investigate the influences of peer feedback on high school students' paragraph writing performance, two questions are examined as follow:

1. What are high school students' most common writing errors as composing a paragraph writing? Are there any differences in common writing errors between the control and experimental group?

2. To what extent does peer feedback impact high school students' paragraph writing performance? What are the students' perspectives towards peer feedback activities?

\section{Method}

\subsection{Research Context and Participants}

This quasi-experimental study was conducted at Hoa Minh High School, founded in 2001 on Long Hoa island of Chau Thanh district, Tra Vinh province. The participants obligatorily chosen for the study were sixty-four students from two classes studying English in grade 11 with the same curriculum among five courses in the academic year 2019-2020. In this study, students were divided into two groups: The experimental group and the control group. The experimental group comprised 32 students (divided into eight small groups of four). It worked in peer feedback activities by using checklists. 
In contrast, the control group (eight smaller groups) had the same number of participants as the experimental group without any specifically trained peer feedback. They conducted peer feedback on their skills and knowledge. All students were required to write the same paragraph writing as a pre-test based on a textbook entitled Tieng Anh 11, published by the Ministry of Education and Training. In particular, the students had practiced writing paragraphs based on five genres: descriptive, example, process, opinion, and narrative. The two groups were involved in the same stages of process writing, commencing from planning, draft, revising, to editing. The students were required to compose a paragraph of 100 to 120 words; then, they conducted peer feedback activities.

The textbook Tieng Anh 11 was used as an official book for school students in grade eleven in Vietnam. The book comprises 16 units; each unit consisted of forty-five-minute periods: Reading, Listening, Speaking, Writing, and Language Focus with many different writing topics. In this present study, the participants have instructed the seven genres of the book: Describing a celebration; writing a formal letter to express dissatisfaction and satisfaction; describing location; describing information from the chart; describing the preparation for the coming Asian Games; writing about a collection; writing a biography. However, the researcher would only choose two units to carry out the experience on students' paragraph writing performance in this study. The research was carried out through twelve weeks, including the pre-test and post-test and semi-structured interviews.

\subsection{Data Collection}

Writing pre-test and post-test were employed in this study to measure their writing outcomes before and after the treatments. They were asked to write a paragraph of about 100- 120 words on specific topics. The writing topic for the pre-test was 'describe your hobbies', and the writing topic for the post-test was 'describe your last weekend activities.'

The writing tests of both groups would be scored through a scoring rubric, which was recorded by all the English teachers in the research context. The scoring rubric was adapted from Weigle (2002), included three main components of writing to be emphasized: content, grammar, and language use. This rubric scoring was used for the inter-rater to evaluate the students' writing paper. The total score is 10 , the maximum score is 10 , and the minimum score is 0 . In addition, to check whether the students' writing progressed or not, the students' writing papers were also measured by counting the number of mistakes in the first and final papers.

The semi-structured interviews were used to gain insights into students' attitudes toward giving feedback to their peers' writings and the expectations of improvement of their writings after receiving written feedback. At the end of the course, five rich-informant students were invited to participate in the semi-structured interviews to explore qualitative data about the usefulness of peer feedback in writing classes, the improvement after giving and receiving peer feedback from their peer' writing, and the interests in peer feedback when implementing peer feedback activities in writing class.

\subsection{Coding Scheme}

To evaluate the effects of peer feedback on students' paragraph writing work on their writing outcome, the pre-test and post-test papers were encoded by two coders to measure the common errors. The coding scheme was focused on three major aspects: grammar, vocabulary, and mechanics. The encoding for students' mistakes correcting is shown in Fig. 1 as an example.

\begin{tabular}{|c|c|c|}
\hline Symbols & Examples & Meaning \\
\hline \multirow[t]{2}{*}{ WF } & Original: I go school today. & Wrong form \\
\hline & Correction: I went to school yesterday & \\
\hline \multirow[t]{2}{*}{ WO } & Original: I like very much this. & Wrong order \\
\hline & Correction: I like this very much. & \\
\hline \multirow[t]{4}{*}{ AG } & Original: My hobbies start when I am in ten years old & Wrong agreement \\
\hline & Correction: My hobbies started when I am in ten years old. & \\
\hline & Original: The hobby I like most $\underline{\text { are playing my guitar. }}$ & \\
\hline & Correction: The hobby I like most is playing my guitar. & \\
\hline \multirow[t]{2}{*}{$\mathrm{T}$} & Original: I visit my grandparents last week. & Wrong tense \\
\hline & Correction: I visited my grandparents last week. & \\
\hline
\end{tabular}


Original: I have had the enjoyable activities last weekend.

Correction: I had the enjoyable activities last weekend.

\begin{tabular}{|c|c|c|}
\hline SP & $\begin{array}{l}\text { Original: She alway helps me and give good advice } \\
\text { Correction: She always helps me and give good advice }\end{array}$ & Wrong spelling \\
\hline Symbols & Examples & Meaning \\
\hline $\mathrm{P}$ & $\begin{array}{l}\text { Original: I stayed there for only three days. And I was very happy. } \\
\text { Correction: I stayed there for only three days, and I was very happy. } \\
\text { Original: I some time go out to chat with my friends } \\
\text { Correction: I sometimes go out to chat with my friends }\end{array}$ & Wrong punctuation \\
\hline WF & $\begin{array}{l}\text { Original: That movie is very well for you to watch in your free time. } \\
\text { Correction: This movie is very good for you to watch in your free time. } \\
\text { Original: I like go to the cinema. } \\
\text { Correction: I like going to the cinema. }\end{array}$ & Wrong form \\
\hline Art & $\begin{array}{l}\text { Original: It was a interesting movie to watch at the weekend. } \\
\text { Correction: It was an interesting movie to watch at the weekend. } \\
\text { Original: I am a student. } \\
\text { Correction: I am a student }\end{array}$ & Article \\
\hline Prep & 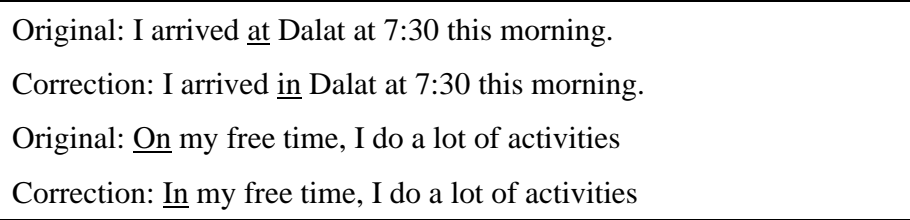 & preposition \\
\hline WW & $\begin{array}{l}\text { Original: My employment is collecting stamps } \\
\text { Correction: My favorite hobby is collecting stamps }\end{array}$ & Wrong word \\
\hline
\end{tabular}

Figure 1. The scheme for encoding students' writing mistakes

To respond to each research question, both quantitative and qualitative data were collected and analyzed. The quantitative data (pre-test and post-test) were collected and analyzed by the SPSS vs. 26 to compare the differences between and within the groups by running the independent sample t-test and paired sample t-test. Qualitative data from the semi-structured interviews were transcribed and organized into themes of content.

\section{Findings \& Discussion}

To evaluate the effects of peer feedback on the students' paragraph writing performance, the students of the two groups did the pre-test to check whether the students' level of writing performance in the two groups before implementing the peer feedback technique on teaching writing. Two raters rated sixty-four writing papers of the students in the two groups. An Independent sample t-test of SPSS vs. 26 was run to compare. The inter-rater reliability of the pre-test of the experimental group was .994, and that of the control group was .98. Table 1 presents the comparison of the pre-tests between the two groups before the treatment.

Table 1. Comparison of the students' writing in the pre-test of the two groups

\begin{tabular}{|c|c|c|c|c|c|c|c|c|}
\hline Writing test & Groups & $\mathrm{N}$ & M & SD & MD & $\mathrm{t}$ & df & Sig. (2-tailed) \\
\hline Pre-test & Experimental & 32 & 3.77 & 1.31 & -.0 .56 & -0.048 & 62 & 0.934 \\
\hline & Control & 32 & 3.78 & 1.31 & & & & \\
\hline
\end{tabular}

* Independent sample t-test

Table 1 shows that the homogeneity test for the results of pre-test from the two groups indicated that the students' pre-test scores were homogeneous. The mean score in the control and experimental groups was $3.78(\mathrm{M}=3.78$; $\mathrm{SD}=$ 
1.31) and $3.77(\mathrm{M}=3.77 ; \mathrm{SD}=1.31)$, respectively. There was no significant difference in individual writing skills between two groups $(-t(62)=.048 ; p=.934 ; p>.05)$. Therefore, the writing skills of students in the two groups were considered equal.

In order to illustrate more clearly the students' paragraph writing performance in terms of common mistakes in both pre-test, all the students' writing errors were counted. The main aim was to focus on some students' common mistakes, Especially, these mistakes related to three main components of writing to be emphasized: grammar (the use of verbs, articles, repositions); vocabulary (words order, words choice, word form); and mechanics (capitalization, spelling, punctuation). An independent sample t-test was run to check the equality of the students' writing skills. The results of students' paragraph writing performance of all of the component mistakes in the pre-tests of the two groups are illustrated in table 2 and a brief summary of three aspects of mistakes.

Table 2. Summary of three aspects of mistakes at pre-test of the two groups

\begin{tabular}{|c|c|c|c|c|c|c|c|}
\hline $\begin{array}{l}\text { Students' mistakes in the } \\
\text { first drafts }\end{array}$ & $\begin{array}{l}\text { Components of } \\
\text { mistakes }\end{array}$ & $\mathrm{N}$ & Mean & SD & $\mathrm{t}$ & $\mathrm{df}$ & $\begin{array}{l}\text { Sig. } \\
\text { (2-tailed) }\end{array}$ \\
\hline Pre-test (E-G) & \multirow[t]{2}{*}{ Grammar } & & 7.19 & 2.16 & & & \\
\hline Pre-test (C-G) & & 64 & 7.13 & 2.46 & 0.11 & 62 & 0.91 \\
\hline Pre-test (E-G) & \multirow{2}{*}{ Vocabulary } & & 4.34 & 1.54 & & & \\
\hline Pre-test (C-G) & & 64 & 4.47 & 2.11 & -0.27 & 62 & 0.79 \\
\hline Pre-test (E-G) & \multirow{2}{*}{ Mechanics } & & 2.50 & 1.27 & & & \\
\hline Pre-test (C-G) & & 64 & 3.22 & 1.66 & -1.95 & 62 & 0.06 \\
\hline \multicolumn{8}{|c|}{ Overall students' mistakes in the first drafts of the } \\
\hline $\begin{array}{l}\text { Overall students' mistakes } \\
\text { control group }\end{array}$ & in the first drafts of the & 64 & 14.81 & 5.41 & -.651 & 62 & .518 \\
\hline
\end{tabular}

As can be seen in Table 2, most of the mistakes at the pre-tests of the two groups related to the three aspects include grammar (the use of verbs, articles, repositions); vocabulary (word order, word choice, word form); and mechanics (capitalization, spelling, punctuation) which showed that the two groups made the number of students' mistakes in each paragraph. The total mean score at the pre-test in the experimental group was $14.03(\mathrm{M}=14.03, \mathrm{SD}=4.11)$ while it was $14.81(\mathrm{M}=14.81, \mathrm{SD}=5.41)$ in the control group $(-\mathrm{t}(62)=-.65, \mathrm{p}=.52 ; \mathrm{p}>0.05)$. The $\mathrm{p}$-values of the statistics reveal that mistakes in grammar and vocabulary were not significantly different. In general, the result showed that there was no statistically significant difference in the mean score of the two groups. Therefore, it could be confirmed that the students of the two groups had similar levels of error mistakes before any intervention.

Research question 1: What are high school students' most common writing errors as composing a paragraph writing? Are there any differences in common writing errors between the control and experimental group?

To respond to this research question, all the students' writing errors or mistakes of the students' writing tests were tallied and compared. Inter-coders, who were also the inter-raters, were employed to code the students' written errors. The reliabilities of the inter-coders were .99 (pre-tests) and .98 (post-tests). First, we used the paired-sample t-tests to compare the students' writing errors in the paragraphs between the pre- vs. post-tests of the two groups to see if there were any differences within the groups. Then, the independent sample t-test was run to compare the post-tests between the two groups. Table 3 shows the comparison between the pre and post-test of the control group in terms of written mistakes in three major aspects, including grammar, vocabulary, and mechanics. It had no significant difference compared to the pre-test. 
Table 3. Students' mistakes in 3-major aspects in the pre-and post-test of the control group

\begin{tabular}{|c|c|c|c|c|c|c|c|c|c|}
\hline \multicolumn{2}{|c|}{ Components of mistakes } & \multirow[t]{2}{*}{$\mathrm{N}$} & \multirow{2}{*}{$\begin{array}{l}\text { Mean } \\
7.13\end{array}$} & \multirow{2}{*}{$\begin{array}{r}\text { SD } \\
2.46\end{array}$} & \multirow[t]{2}{*}{ Correlation } & \multirow[t]{2}{*}{ MD } & \multirow[t]{2}{*}{$\mathrm{t}$} & \multirow[t]{2}{*}{ df } & \multirow[t]{2}{*}{$\begin{array}{c}\text { Sig. } \\
\text { (2-tailed) }\end{array}$} \\
\hline Pre-test (CG) & & & & & & & & & \\
\hline Post-test (CG) & Grammar & 32 & 5.97 & 2.13 & .78 & .13 & 4.17 & 31 & .000 \\
\hline Pre-test (CG) & & & 4.47 & 2.11 & & & & & \\
\hline Post-test (CG) & Vocabulary & 32 & 4.34 & 1.98 & .98 & .13 & 1.68 & 31 & .103 \\
\hline Pre-test (CG) & & & 3.22 & 1.66 & & & & & \\
\hline Post-test (CG) & Mechanics & 32 & 3.13 & 1.58 & .98 & .09 & 1.79 & 31 & .083 \\
\hline
\end{tabular}

* Paired sample t-tests

Table 3 reveals the control group students' written mistakes or errors in three major aspects: grammar, vocabulary, and Mechanics in the pre and post-tests. In total, 32 written paragraphs in the pre-test had 288 errors in grammar (verbs, articles, repositions), while 32 written paragraphs in the post-test 32 written paragraphs committed to 191 errors in grammar. Regards to errors in vocabulary (word order, word choice, word form), 32 written paragraphs in the pre-test had 143 errors, whereas those post-test paragraphs were slightly reduced to 139 errors in vocabulary. Regarding mechanical errors such as capitalization, spelling, and punctuation, 32 pre-test papers committed to 103 in mechanical errors, and 32 post-test papers remained similar to 100 mechanical errors.

Table 3 also reveals that of 32 paragraph writings, each paragraph writing of the pre-test, on average, made seven errors in grammar $(M=7.13$; $S D=2.46)$, while it had made six grammatical errors $(M=5.97 ; S D=2.13)$ in the post-test. Relating to errors in vocabulary, each paper in the pre-test made four errors in vocabulary $(\mathrm{M}=4.47 ; \mathrm{SD}=$ $2.11)$, and it had the same number of errors in the post-test $(\mathrm{M}=4.34 ; \mathrm{SD}=1.98)$. With regards to errors in mechanics, each pre-test paper had three errors in mechanics $(\mathrm{M}=3.22 ; \mathrm{SD}=1.66)$, and it made a similar number of errors in the post-test $(\mathrm{M}=3.13 ; \mathrm{SD}=1.58)$. The results of the paired sample t-tests indicate that only grammatical errors were statistically significantly different $(\mathrm{t}(31)=4.17, \mathrm{p}=.00 ; \mathrm{p}<0.01)$; mistakes in both vocabulary and mechanics were not different statistically. In other words, the students in the control group, without any training of peer feedback, could help each other reduce grammar mistakes, but not in vocabulary and mechanics. Table 4 presents the comparison of the students' written errors between the pre and post-test of the experimental group.

Table 4. Students' mistakes in 3-major aspects in the pre-and post-test of the experimental group

\begin{tabular}{|c|c|c|c|c|c|c|c|}
\hline Writing performance in & Components & & & & & & Sig. (2-tailed) \\
\hline Experimental Group & mistakes & $\mathrm{N}$ & Mean & SD & $\mathrm{t}$ & df & \\
\hline Pre-test (EG) & & & 7.19 & 2.16 & & & \\
\hline Post-test (EG) & Grammar & 32 & 2.41 & 1.66 & 14.14 & 31 & .000 \\
\hline Pre-test (EG) & & & 4.34 & 1.54 & & & \\
\hline Post-test (EG) & Vocabulary & 32 & 1.83 & .859 & 10.13 & 31 & .000 \\
\hline Pre-test (EG) & & & 2.50 & 1.27 & & & \\
\hline Post-test (EG) & Mechanics & 32 & 1.34 & .61 & 4.67 & 31 & .000 \\
\hline
\end{tabular}

* Paired sample t-tests

As presented in table 4, 32 written paragraphs of the pre-test of the experimental group had 230 errors in grammar relating to verbs, articles, and repositions. However, 32 post-test papers reduced remarkably to 77 errors in grammar. Regards to errors in vocabulary, such as word order, word choice, and word form, 32 pre-test papers made 139 errors, whereas the 32 post-test papers made only 58 errors. Next, relating to mechanical errors (capitalization, spelling, 
punctuation), 32 written papers committed to 80 errors in the pre-test, while they reduced to nearly a half, 44 errors in mechanics.

Of 32 paragraph written papers of the experimental group in the pre-test, each written paper in the pre-test made seven errors in grammar (verbs, articles, prepositions) $(M=7.19 ; \mathrm{SD}=2.16)$. However, these kinds of errors reduced significantly to 2 errors in grammar $(\mathrm{M}=2.41 ; \mathrm{SD}=1.66)$. Relating to errors in vocabulary (word order, word choice, word form), of 32 written papers in the pre-test, each paper made four errors $(\mathrm{M}=4.34 ; \mathrm{SD}=1.54)$, while each in the post-test had two errors in vocabulary $(\mathrm{M}=1.83 ; \mathrm{SD}=.86)$. With regards to the errors in mechanics (capitalization, spelling, punctuation), each pre-test paper was committed to 2.5 errors $(\mathrm{M}=2.50 ; \mathrm{SD}=1.27)$, whereas each paper in the post-test had approximately 1 error in mechanical aspects $(\mathrm{M}=1.34 ; \mathrm{SD}=.61)$. The results of the paired sample t-tests showed that there were statistically significant differences in the written errors between the pre-test and post-test of the experimental group. The p-values, in term of grammatical mistakes $(\mathrm{t}(31)=14.14, \mathrm{p}=.000<0.05)$, vocabulary $(\mathrm{t}(31)=10.13, \mathrm{p}=.00<0.05)$, and mistakes of mechanics $(\mathrm{t}(31)=4.67, \mathrm{p}=.00<0.05)$ indicate that there were remarkable reductions. It could be confirmed that the students of the experimental group had a remarkable improvement on paragraph writing performance, especially, they had been highly improved on grammar, vocabulary, and mechanics. Table 5 presents the comparison of the post-tests between the two groups.

Table 5. 1comparison of the post-tests between the two groups

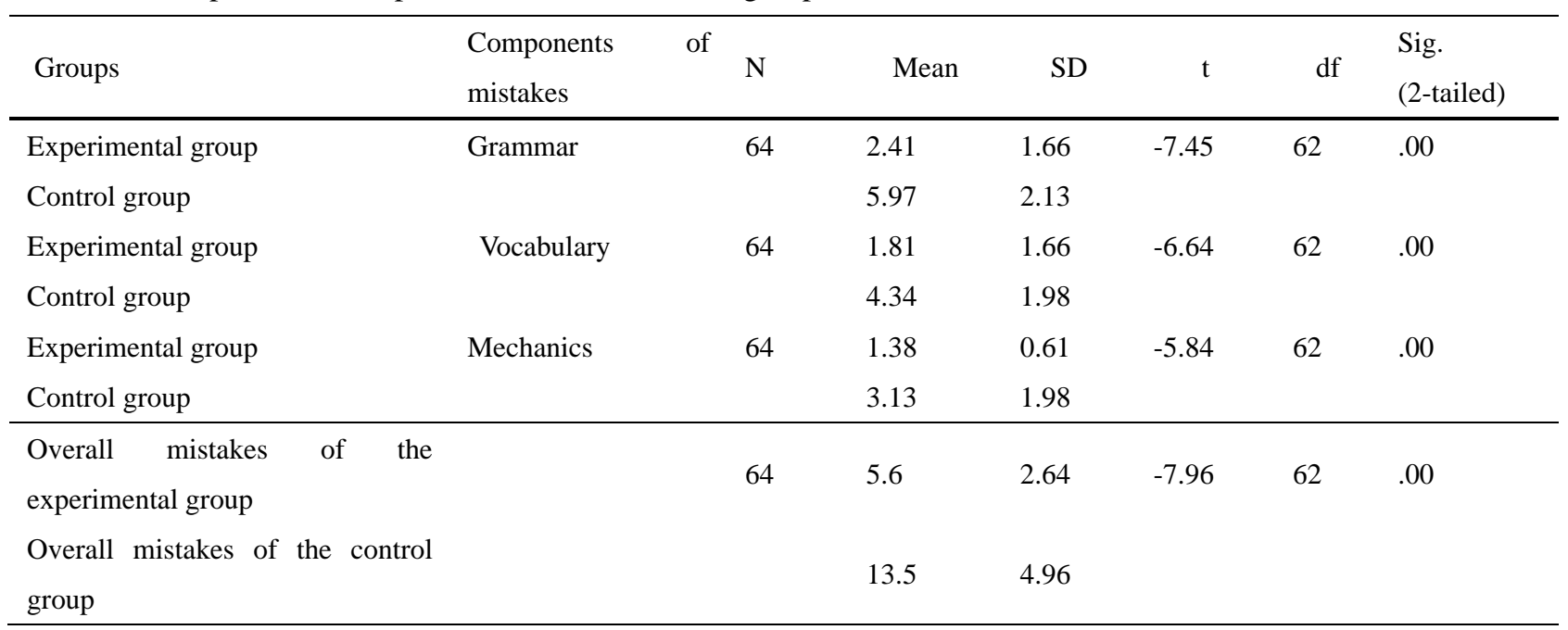

* Independent sample t-tests

As shown in Table 5, of 32 written paragraphs in the post-test, each paper of the students in the experimental group made six mistakes, on average, in grammar, vocabulary, and mechanics $(\mathrm{M}=5.60, \mathrm{SD}=2.64)$. However, each paper of the control group made 13 errors, on average $(\mathrm{M}=13.5 ; \mathrm{SD}=4.96)$. The $\mathrm{p}$-value of the independent sample $\mathrm{t}$-test revealed a statistically significant difference in written errors between the two groups in the post-tests. In other words, the students in the experimental group who received peer feedback training could obtain great reductions of written errors in the post-test. In other words, the students in the experimental group could produce better writing products after they received the treatment. This finding confirmed the effects of peer feedback training by previous studies such as Berg (1999), Tuzi (2004), Pham and Usaha (2016), Pham et al. (2020), and Pham (2021).

The findings of the present study were also consistent with some previous studies such as Tsui and $\mathrm{Ng}(2000)$, Lundstrom and Baker (2009); Farid and Samad (2012); Yastıbaş (2015). For instance, Tsui and Ng (2000) reported that peer feedback improved their students' writing skills and ideas. In addition, their students felt comfortable while exchanging ideas in the peer feedback process, and they felt much more comfortable in the writing class.

Research question 2: To what extent does peer feedback impact high school students' paragraph writing performance? What are the students' perspectives towards peer feedback activities?

To seek answers to these research questions, I would compare all the students' written paragraphs of the pre-tests to those composed in the post-tests. All the scores rated by the inter-raters were used to compare the paired sample t-tests and independent sample t-tests of SPSS vs. 26. The Cronbach's Alpha of the inter-raters for the control group 
was .97 , and that of the experimental group was .96. Table 6 shows the comparison of the two groups between the pre-tests and post-tests.

Table 6. Comparison between the pre and post-test of the two groups

\begin{tabular}{llllllllll}
\hline Writing performance & & $\mathrm{N}$ & $\mathrm{M}$ & $\mathrm{SD}$ & $\mathrm{MD}$ & Correlation & $t$ & $d f$ & Sig.(2-tailed) \\
\hline Control group & Pre-test & 32 & 3.78 & 1.31 & -0.28 & 0.79 & -1.96 & 31 & .059 \\
& Posttest & 32 & 4.06 & 1.13 & & & & \\
\hline \multirow{2}{*}{ Experimental group } & Pre-test & 32 & 3.77 & 1.31 & -1.59 & 0.679 & -8.91 & 31 & .000 \\
& Posttest & 32 & 5.36 & 1.20 & & & & \\
\hline
\end{tabular}

* Paired sample t-test

Table 6 displays the comparison of the scores rated by the inter-raters between the pre-tests and post-tests of the two groups. As can be seen, each of the students' written paragraphs gained 3.78 scores in the pre-test $(\mathrm{M}=3.78$; SD = 1.31), and those in the post-test received $4.06(\mathrm{M}=4.06 ; \mathrm{SD}=1.13)$. There seemed to be an increase in the scores gained by the students in the post-test. However, the paired sample t-test $(\mathrm{t}(31)=-1.96 ; \mathrm{p}=.059 ; \mathrm{p}>.05)$ indicates that there was no statistically significant difference in the scores between the pre-test and post-test in the control group. In other words, the students who conducted peer feedback without any specific training from the teacher did not improve their writing outcome much.

Also, as illustrated by table 6 , of 32 pre-test written paragraphs of the experimental group, each paper received 3.77 scores in the pre-test by the inter-raters $(\mathrm{M}=3.77 ; \mathrm{SD}=1.31)$. In the post-test, each paper gained 5.36 scores $(\mathrm{M}=5.36$; $\mathrm{SD}=1.20)$. The mean difference was -1.59 . The $\mathrm{p}$-value of the paired sample $\mathrm{t}$-test $(\mathrm{t}(31)=-8.91 ; \mathrm{p}=.00 ; \mathrm{p}<.01)$ indicates that there was a statistically significant difference between the pre and post-test scores of the experimental group. That is, the students in the experimental group who conducted peer feedback with guideline training could produce better versions of paragraph writing after the treatment. Table 7 presents the comparison of the post-tests between the two groups.

Table 7. Comparison of writing outcomes of the post-tests between the two groups

\begin{tabular}{llccccccc}
\hline Writing outcomes & Groups & N & M & SD & MD & $t$ & $d f$ & Sig. (2-tailed) \\
\hline Post-test & Experimental & 32 & 5.36 & 1.20 & 1.14 & 4.44 & 62 & .00 \\
& Control & 32 & 4.06 & .83 & & & & \\
\hline
\end{tabular}

* Independent sample t-test

In order to see whether treatment was more effective or to confirm previous studies (Berg, 1999; Tuzi, 2004; Pham \& Usaha, 2016, Pham et al., 2020, and Pham, 2021) that the trained peer feedback really influenced the students' writing outcomes, post-tests of the two groups was compared. Table 7 reveals that each paper of the experimental group gained 5.36 scores rated by the inter-raters $(\mathrm{M}=5.36 ; \mathrm{SD}=1.20)$, whereas each paragraph writing of the control group received 4.06 scores $(M=4.06 ; \mathrm{SD}=.83)$. The independent sample t-test $(\mathrm{t}(62)=4.44 ; \mathrm{p}=.00 ; \mathrm{p}<.01)$ shows that there was a statistically significant difference between the two groups in the post-tests. The students in the experimental group improved their written paragraphs far better than those in the control group.

The following session was the qualitative data from the semi-structured interviews. The purpose of the interview was to gain more insights into participants' attitudes towards giving and receiving peer feedback. After taking the writing post-tests, five participants in the experimental group were invited to participate in the interviews. Five students stated that their friends' feedback was understandable because they shared similar levels of English proficiency, and peer feedback helped them to interact with each other in a positive way.

Most of the students confirmed that they were happy to receive peer feedback to correct their errors in their papers. Receiving feedback from peers could reduce their anxiety in writing in English. They felt more confident in writing in English.

... I think that my writing is not perfect, and it needs to be corrected, so my friend corrects me; I have appreciated my friends very much for pointing out those mistakes. I am confident to write better. 
(Student 1)

... Feedback activities in writing class can help me with developing my writing skills. More than that, I can find the mistakes by myself, and then I can correct them quickly. ... It helps me identify the mistakes in my writing, and then I can correct them based on the guideline sheet or the checklist. (student 5)

Most students agreed that receiving and giving feedback to their friends enabled them to correct their own mistakes in writing. They mentioned that most of their peers made similar mistakes, so it was easy for them to provide comments to their peer papers and correct their own mistakes.

I feel very happy when my friends give comments on the mistakes in my paragraph writing, and since then, I have known how to correct my mistakes in writing. As I find similar mistakes or errors on my peer papers, I can also give suggestions to my friends to correct them because some of my classmates also make these similar mistakes. (student 2)

Most students expressed their preference for utilizing peer feedback activities in their writing classroom. They reported that they liked using peer feedback in writing classes because it helped them to learn different writing styles from their friends' comments and writing. They felt more motivated in writing with the support of the comments from teachers and friends. Besides, they admitted that the peer feedback technique in writing helped them facilitate their writing, and they thought it was very interesting and motivated them to write. For instance, students 3 and student 4 perfectively answered

... I like using peer feedback activity in the writing classroom because I can have many different opinions and can discuss with each other. I feel... I can know how my friends express their ideas and thinking in different ways, and know more useful information. (Student 3)

... using peer feedback activity in the group makes me excited to write naturally and makes me think more. (student 4)

All five students realized that peer feedback is a useful activity and brought them some beneficial aspects, such as engaging in the lesson, increasing their interaction between group members, having more motivation in the learning process, and improving their language achievement.

... I find using peer feedback a lot of benefits while I am learning to write... I feel that my classmates also give out many good ideas to help me write better complete sentences (student 4).

... I think that giving feedback to my friends has many benefits, such as it can help me improve my vocabulary, and I also learn new words from my friends to help me understand and remember longer. (Student 5)

... I have more ideas, and then I write. I have friends to support words and grammar. Sometimes there are very simple errors that I do not detect, but when my friends read, they immediately discover them (student 1)

... I had improved more than before because I edited and presented the ideas logically. Also, I also learn many new words from my friends (student 2).

In addition, some of the students expressed their attitude toward the usefulness of peer feedback. They considered their peer feedback to be as effective as the teacher's feedback.

... I think that peer feedback works just as well as the teacher's feedback to correct our homework, but I can easily correct it because we work together to fix it to help me remember the lesson longer, and I also learn from friends. (Student 2)

... I think that my peer feedback is very effective, and it helps me a lot. I find it is as effective as the teacher's feedback because we have a checklist to easily find errors (Student 1).

The findings of the current study were also in agreement with previous studies such as Shrum and Glisan (2000); Yang et al. (2006); Lundstrom and Baker (2009); Farrah (2012); Park (2018). For example, Ferris (1995) stated that students enhance their critical thinking skills and confidence as a result of reading text written by peers on similar tasks. Yang et al. (2006) reported that peer feedback has distinct learning advantages and qualified learners to be independent thinkers and creative writers. Another example, Wakabayashi (2008) and Farrah (2012) found that peer feedback strategy makes students receive comments from the student's perspective, enhances critical reading and critical thinking skills, and involves sharing ideas and receiving feedback. It also gains students' 
audience awareness. In other words, students are thinking as a reader that will improve their writing as well.

The qualitative data in the current study also claimed that the students had a positive attitude toward the improvement after receiving peer feedback from their peers. This was in line with some previous studies such as Jacobs (1981); Ferris (1995); Weigle (2002); Farrah (2012); Cahyono and Rosyida (2016); Park (2018); Kusumaningrum et al. (2019); Pham et al. (2020). For example, Kusumaningrum et al. (2019) evaluated the influence of two types of peer feedback provision on the students' writing performance. The result revealed that the students improved their writing performance after being exposed to either in-class peer feedback or small group peer feedback. Farrah (2012) found that students viewed peer feedback as a worthwhile experience; it offered an opportunity for social interaction. It also improved students' writing skills. Moreover, the technique enhanced students' critical thinking, motivation, creativity, and confidence and helped improve their assignments.

Some previous studies, such as Farrah (2012), Yastıbaş and Yastıbaş (2015), indicated that the students who used peer feedback in the writing class decreased their writing anxiety, increased their confidence, and improved their writing by collaborating with and learning from each other. Farrah (2012) asserted that students viewed peer feedback as a worthwhile experience; it offered an opportunity for social interaction. It also improved students' writing skills. Moreover, the technique enhanced students' critical thinking, motivation, creativity, and confidence and helped improve their assignments.

\section{Conclusion}

The present study aimed to examine whether peer feedback had any effects on high school students' paragraph writing performance among students grade 11 at Hoa Minh High School. The study setting was at two classes at the same school with sixty-four students to participate in this research near the end of the second semester of the academic year 2019-2020. Data collection was from the pre-test, post-test, and semi-structured interviews. The pre-test and post-test results showed that after 16 weeks of implementing the peer feedback activities in the teaching writing classes, the mean score of the experimental group was higher than that of the control group in the post-test. The results indicated that the most common errors that the students committed were grammar (verbs, articles, repositions), followed by vocabulary (word order, word choice, word form), and mechanics (capitalization, spelling, punctuation). In addition, the students in the experimental group who received peer feedback training could greatly reduce the written errors in the post-test. There were significant differences between the mean score of the pre-test and post-test in the experimental group. Especially, there was an improvement in the quality of paragraph writing performance of the students in the experimental group compared with those in the control group. Additionally, the students in the experimental group reduced mistakes in writing text after implementation of the peer feedback in comparison with those in the control group. This confirmed that the students in the experimental group gained better improvement in their writing skills. Their written errors or mistakes were reduced significantly in the post-tests. Moreover, the participants in the experimental group agreed that they liked this treatment and thought that peer feedback should be introduced and applied in the teaching context of high schools.

\section{References}

Altstaedter, L. L. (2018). Investigating the impact of peer feedback in foreign language writing. Innovation in Language Learning and Teaching, 12(2), 137-151. https://doi.org/10.1080/17501229.2015.1115052

Bahrpeyma, M., \& Ostad, O. (2018). Error analysis of composition writing: A case of Iranian EFL learners. International Journal of Research Studies in Language Learning, 7(2), 101-112. https://doi.org/10.5861/ijrsll.2017.1694

Berg, E. C. (1999). The effects of trained peer response on ESL students' revision types and writing quality. Journal of second language writing, 8(3), 215-241. https://doi.org/10.1016/S1060-3743(99)80115-5

Cahyono, B., \& Rosyida, A. (2016). Peer feedback, self-correction, and writing proficiency of Indonesian EFL students. Arab World English Journal (AWEJ), 7(1), 178-193. https://doi.org/10.24093/awej/vol7no1.12

Chan, A. Y. (2010). Toward a taxonomy of written errors: Investigation into the written errors of Hong Kong Cantonese ESL learners. Tesol Quarterly, 44(2), 295-319. https://doi.org/10.5054/tq.2010.219941

Damon, W., \& Phelps, E. (1989). Critical distinctions among three approaches to peer education. International journal of educational research, 13(1), 9-19. https://doi.org/10.1016/0883-0355(89)90013-X

Darus, S., \& Ching, K. H. (2009). Common errors in written English essays of form one Chinese students: A case study. European Journal of social sciences, 10(2), 242-253. 
Farid, S., \& Samad, A. A. (2012). Effects of different kind of direct feedback on students' writing. Procedia-Social and Behavioral Sciences, 66, 232-239. https://doi.org/10.1016/j.sbspro.2012.11.265

Farrah, M. (2012). 4 The impact of peer feedback on improving the writing skills among Hebron university students. An-Najah Univ. J. Res. (Humanities), 26(1), 179-210.

Ferris, D. (1995). Students reactions to teacher response in multiple draft composition classrooms. TESOL Quarterly, 29, 33-53. https://doi.org/10.2307/3587804

Gielen, S., Tops, L., Dochy, F., Onghena, P., \& Smeets, S. (2010). A comparative study of peer and teacher feedback and of various peer feedback forms in a secondary school writing curriculum. British educational research journal, 36(1), 143-162. https://doi.org/10.1080/01411920902894070

Graham, S., \& R. Harris, K. (2000). The role of self-regulation and transcription skills in writing and writing development. Educational Psychologist, 35(1), 3-12. https://doi.org/10.1207/S15326985EP3501_2

Ho, P. V. P. (2014). Những hạn chế trong phương pháp dạy và học môn viết tại khoa ngoại ngữ trường Đại học Mở Thành phố Hồ Chí Minh. KHOA HỌC XÃ HỘI, 9(1), 127-140.

Jacobs, G. (1987). First experiences with peer feedback on compositions: Student and teacher reaction. System, 15(3), 325-333. https://doi.org/10.1016/0346-251X(87)90006-6

Keh, C. L. (1990). Feedback in the writing process: A model and methods for implementation. ELT Journal, 44(4), 294-304. https://doi.org/10.1093/elt/44.4.294

Khansir, A. A., \& Pakdel, F. (2020). A Study of Written Errors of Iranian Learners: A Systematic Review. Theory and Practice in Language Studies, 10(8), 982-987. https://doi.org/10.17507/tpls.1008.18

Kusumaningrum, S. R., Cahyono, B. Y., \& Prayogo, J. A. (2019). The Effect of Different Types of Peer Feedback Provision on EFL Students' Writing Performance. International Journal of Instruction, 12(1), 213-224. https://doi.org/10.29333/iji.2019.12114a

Lundstrom, K., \& Baker, W. (2009). To give is better than to receive: The benefits of peer review to the reviewer's own writing. Journal of Second Language Writing, 18, 30-43. https://doi.org/10.1016/j.jslw.2008.06.002

Mangelsdorf, K., \& Schlumberger, A. (1992). ESL student response stances in a peer-review task. Journal of Second Language Writing, 1(3), 235-254. https://doi.org/10.1016/1060-3743(92)90005-A

Park, T. (2018). Effectiveness of Teacher and Peer Feedback: Through the Lens of Korean Tertiary Writing Classroom. 15(2), 257-565. https://doi.org/10.18823/asiatefl.2018.15.2.11.429

Pham V. P. H., Luong, T. K. P., Tran, T. T. O., \& Nguyen, Q. G. (2020). Should Peer E-Comments Replace Traditional Peer Comments? International Journal of Instruction, 13(1), 295-314. https://doi.org/10.29333/iji.2020.13120a

Pham, V. P. H. (2021). The Effects of Collaborative Writing on Students' Writing Fluency: An Efficient Framework for Collaborative Writing. SAGE Open, 11(1), 1-11. https://doi.org/10.1177/2158244021998363

Pham, V. P. H. (2021). The Effects of Lecturer's Model e-comments on Graduate Students' Peer e-comments and Writing Revision. Computer Assisted Language Learning, 34(3), 324-357. https://doi.org/10.1080/09588221.2019.1609521

Pham, V. P. H., \& Bui, T. K. L. (2021). Genre-based Approach to Writing in EFL Contexts. World Journal of English Language, 11(2), 95-106. https://doi.org/10.5430/wjel.v11n2p95

Pham, V. P. H., \& Do, T. P. T. (Dec. 2019). High School Students' Common Errors in Writing Essays. International Journal of English Linguistics, 9(6), 309-319. https://doi.org/10.5539/ijel.v9n6p309

Pham, V. P. H., \& Nguyen, N. H. V. (2020). Blogging for Collaborative Learning in the Writing Classroom. International Journal of Cyber Behavior, Psychology and Learning (IJCBPL), 10(3), 1-11. https://doi.org/10.4018/IJCBPL.2020070101

Pham, V. P. H., \& Nguyen, T, B, (2014). The Effects of Communicative Grammar Teaching on Students' Achievement of Grammatical Knowledge and Oral Production. English Language Teaching (ELT), 7(6), 74-86. https://doi.org/10.5539/elt.v7n6p74

Pham, V. P. H., \& Pham, N. T. D. (2015). Common Errors in Writing Journals of the English-Major Students at HCMC Open University. Journal of Science - HCMC Open University, 2(14), 52- 61. 
Pham, V. P. H., \& Siriluck, U. (2016). Blog-based Peer Response for L2 Writing Revision. Computer Assisted Language Learning, 29(4), 724-748. https://doi.org/10.1080/09588221.2015.1026355

Pham, V. P. H., Huyen, L. H., \& Nguyen, M. T. (2020). The incorporation of quality peer feedback into writing revision. Asian Journal of Applied Linguistics, 7(1), 45-59. Retrieved from https://caes.hku.hk/ajal/index.php/ajal/article/view/732

Rahimi, A., \& Tafazoli, D. (2014). Error Analysis In Technology-Mediated Communication: Focus On EFL Writing In Synchronous And Asynchronous Modes Of Communication. Procedia - Social and Behavioral Sciences, 136, 66-69. https://doi.org/10.1016/j.sbspro.2014.05.289

Salehi1, M., \& Bahrami, A. (2018). An error analysis of journal papers written by Persian authors. Cogent Arts \& Humanities, 5, 1-16. https://doi.org/10.1080/23311983.2018.1537948

Shrum, J. L., \& Glisan, E. W. (2002), Teacher's Handbook: contextualized language instruction. Heinle \& Heinle college foreign language.

Tsui, A. B., \& Ng, M. (2000). Do secondary L2 writers benefit from peer comments? Journal of Second Language Writing, 9(2), 147-170. https://doi.org/10.1016/S1060-3743(00)00022-9

Tuzi, F. (2004). The impact of e-feedback on the revisions of L2 writers in an academic writing course. Computers and composition, 21(2), 217-235. https://doi.org/10.1016/j.compcom.2004.02.003

Wakabayashi, R. (2008). The effect of peer feedback on EFL writing: Focusing on Japanese university students. OnCUE Journal, 2(2), 92-110.

Weigle, S. C. (2002). Assessing writing. Ernst Klett Sprachen. https://doi.org/10.1017/CBO9780511732997

Yang, M., Badger, R., \& Yu, Z. (2006). A comparative study of peer and teacher feedback in a Chinese EFL writing class. Journal of Second Language Writing, 8(3), 265-289. https://doi.org/10.1016/j.jslw.2006.09.004

Yastıbaş, G. Ç., \& Yastıbaş, A. E. (2015). The effect of peer feedback on writing anxiety in Turkish EFL (English as a foreign language) students. Procedia-Social and Behavioral Sciences, 199, 530-538. https://doi.org/10.1016/j.sbspro.2015.07.543

Yousefi, S., Soori, A., \& Janfaza, A. (2014). Common Preposition Errors Committed by Iranian Students. International Journal of Applied Linguistics \& English Literature, 3(3), 1-9. https://doi.org/10.7575/aiac.ijalel.v.3n.3p.1

Zimmerman, B. J., \& Risemberg, R. (1997). Becoming a self-regulated writer: A social cognitive perspective. Contemporary Educational Psychology, 22, 73-101. https://doi.org/10.1006/ceps.1997.0919

\section{Copyrights}

Copyright for this article is retained by the author(s), with first publication rights granted to the journal.

This is an open-access article distributed under the terms and conditions of the Creative Commons Attribution license (http://creativecommons.org/licenses/by/4.0/). 